University of Louisville

ThinkIR: The University of Louisville's Institutional Repository

Electronic Theses and Dissertations

$5-1922$

\title{
The regular army as a factor in maintaining peace in the United States.
}

A. Robert Ginsburgh (Abraham Robert) 1895-1958

University of Louisville

Follow this and additional works at: https://ir.library.louisville.edu/etd

\section{Recommended Citation}

Ginsburgh, A. Robert (Abraham Robert) 1895-1958, "The regular army as a factor in maintaining peace in the United States." (1922). Electronic Theses and Dissertations. Paper 498.

https://doi.org/10.18297/etd/498

This Master's Thesis is brought to you for free and open access by ThinkIR: The University of Louisville's Institutional Repository. It has been accepted for inclusion in Electronic Theses and Dissertations by an authorized administrator of ThinkIR: The University of Louisville's Institutional Repository. This title appears here courtesy of the author, who has retained all other copyrights. For more information, please contact thinkir@louisville.edu. 


\section{UNIVERSITY OF LOUISVILLE}

THE REGULAR ARMY AS A FACTOR IN MAINTAINING PEACE IN THE UNITED STATES.

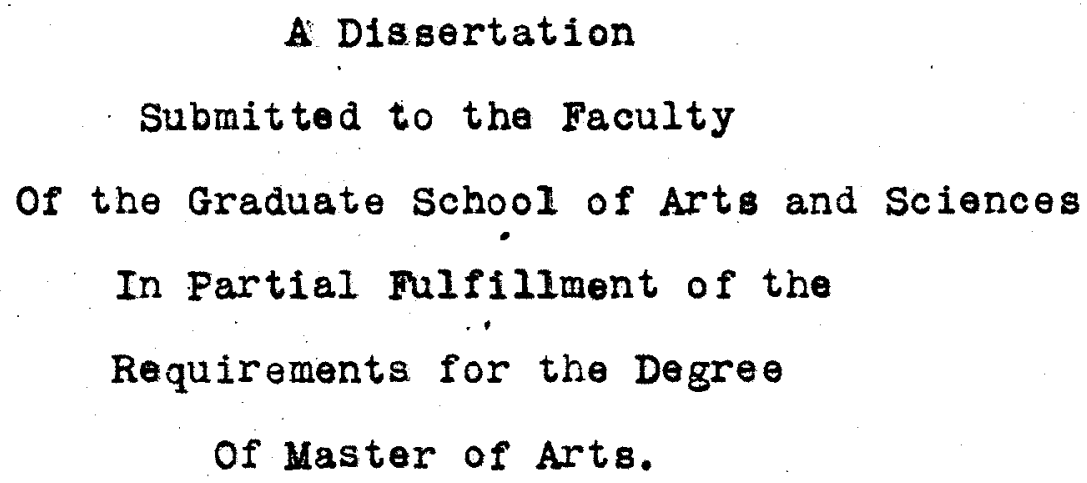

A Dissertation

Submitted to the Faculty

Of the Graduate School of Arts and Sciences

In Partial fulfillment of the

Requirements for the Degreo

of Master of Arts.

Department of History

By

A. Robert Ginsburgh

1922. 


$$
\pm \text {. }
$$

is The function of the army of the United States is to protect the country against all enemies- for- ign and domestic. Everyone is cognizant of the accomplishments of the American forces against its foreign enemies; but there is another work, of equal importance, fraught with as great a danger, which is too often overlooked- that is, the use of the army as an auxiliary force to strengthen the arm of munieipal authority, in the suppression of riots and disturbances; and to maintain order, where for some reason or other, the municipal authority has been unable to cope with the situation. Wars against foreign enemies are usually of very short duration, but the war against the disturbers of the peace within the continental limits of the United States has gone on 1. from day to day. The Armistice was signed November 11, 1918 but hardly a day has passed since then but that somewhere in this country regular troop were in some capacity or other helping in the maintenance of law and order. In the year July 1919-20, for instance

1. Report sec. War 1920. 
regulars were on duty practically every day of the year. It is important to note the variety of occalions which called for troaps and the universality of the appeal for their use. There were strikes, I.W.W. activities, race riots and floods that called for regular troops; and to nawe but a fow of the states whence the appeal came- there was Pennsylvania, Texas, Oklahoma, Nebraska, Indiana, Washington, Montana and Georgia. The whole history of the work of the regular army in the United States shows that although these last few years have been rather troublesome and have called for more than a due how of force the army has boen doing such work since the earliest times. To those who have followed closely the activities of the military establishment it is merely necessary to name a few of the memorable occasions where the army played a very important part- the San Francisco earthquake, the Chinese troubles and the strikes of 1877 and 1894.

In a democratic country, as the United states the military establishment is essentially under the complete control of the civil authorities. To safe- 
guard the constitution and the people against any usurpation of power by the military authorities, certain well known and strictly defined limitations have been placed on its power. Appropriations for the army cover but two years. A state cannot maintain armed traops in time of peace. Soldiers are not to be quartered in times of peace in the homes of citizens. These constitutional principles and others, besides a great many statutes, safeguard civilian institutions against military control. It stands to reason therefore that calling for military aid on the part of municipal authority is an admission of its own inability to handle a situation according to the usual normal process. The use of troops by the federal government shows that its sheriffs, and its civilian agencies for executing the laws of the country have failed to meet a crisis under their jurisdiction.

The calling out of federal troops is a very grave and serious matter. The army is essentially based on discipline and its action is prompt and surnmary- not necessarily arbitrary but it must essentially bear of no delay. To call in the army is also 
to call in its machinery and its mode of operation. The army cannot afford to delay legal process by allowing trial by jury when in the face of a serious riot it becomes necessary to lock a man in jail without trial and even refuse him the writ of habeas corpus. Fortunately in dealing with civilians the army has been cautious to an extraordinary degree and if it has over erred at all, it has always made its mistake to the advantage of the civilian. That does not alter the proposition that the army acts promptly and directly in the way to which it has accustomed itself by its training in field and barracks. In the last analgsis it means that the ultimate modus operandi is martial law, when the military authority temporarily assumes command and administers the civilian population by the same rules that it does the military establishment. To be sure, it has never been necessary to go to that extreme, but that is because the "necessity" had not existed. Had the necessity arisen or should it arise, the military commander would have to take the responsibility of assuming full and complete authority. There, too, is his dilemna; if he does not use 
sufficient force and the army fails to establish law and order by vittue of his negligence, he is subject to court-martial. Shoufd he employ more summary meansor undue force- than are regarded as absolutely necessary, the civilian population or any indivicual may have him brought before a civilian tribunal with equalIy dire consequences. It is, therefore, of the gravest importance for him to know the principles of martial Iaw.

1. Martial law has been defined as the "suspension of ordinary law and the temporary government of a coun2. try, or parts of it, by military tribunals". It should not be confused with military law, which is the "legal system that regulates the government of the military establishment", and is covered in the court-martial manuals of the various countries. Too often, also, is martial law mistaken for military government. The latter is the law of hostile occupation, the military power exercised by a belligerent by virtue of actual occupetion of the territory over its territory and people. This lies in the realm of International law. Martial law, then, is a domestic fact and represents a relation-

1. Dicey- Law of Const. - 280

2. Manual Court-Martial, War Depertment, 1920, page 3. 
ship between the civilian population of a nation and its own military establishment.

The term martial law has been very odious to the Anglo-Saxon and to his institutions. It hearkens back to earlier English History in the periods of the Tudors and Stuarts, when English sovereign employed the army to further their own interests by rendering assistance against the peaple. To maintain peace at home, the King's prerogative allowed him to call upon his troops whenever he deemed it necessary. He abused that power. Somehow to the Anglo-Saxon mind the phrase, martial law, has always meant the irresponsible power wielded by an autocratic ruler over his people by means of the army.

Stripped of its abuses, however, martial law at times not only becomes necessary to the welfare of the state but absolutely essential to its very existence. There are times in the life of every republican state when the lawless elements, mistaking license for liberty, take the laws in their own hands and a reign of anarchy is instituted, which rocks the very foundation of the government. The time, then, is improper, 
to say the least, to argue over the matter. Force must be met by force. It is the fundamental principle of a national existence for the state to repel the thrust at its very life. No government worthy of the nawe will allow itself to be overturned, its objects defeated and its institutions destroyed in the face of such a calamity. It will use the ordinary means at its disposal to counteract the attack, but if it cannot accomplish the work in the normal process it will appeal to the extraordinary- to the unwritten law of the state, if we care to call it such. How much force should be employed is a question; but just as much as is necessary to prevent the state from being overthrown. That extraordinary force to answer the appeal is in the last resort, the military establishment and its operations must necessarily be carried on through a reign of martial law.

It seems that all states realizing that such situations have arisen in the history of all nations, would have made adequate provision for the exigency of military control over civil affairs in their constitutions and statutes; and this has been the custom an the continent. It is the system employed in repub- 
lican France. Provision is made for three conditions of society: the state of peace, the normal Iffe; the state of war, and the state of siege, when in periods of distress the civil law is suspended temporarily and placed subordinate to the authority of the mili1. tary power. The state of siege in France can be egtablished "by statute or if Parliament is not in session it can be made by the president; but in that case, in order to meet the danger of a coup d'etat, which is ever present in the eyes of a Frenchman it is provided that the chambers shall meet as of right in two days. Within the district covered by the state of siege the military courts can be given criminal jurisdiction and can punish any offenses against the safety of the republic or the general peace. They can gearch houses by day or night; expel from the districts any non-residents; seize all arms and forbid any publications which are liable to disturb the public order." In places in a state of siege the authority with which the magistrates are clothed for the maintenance of order and police passes in its entirety to the commander of troops, who exercises it or delegates to them 
1. such part of it as he thinks proper.

France, then, does not have the problem of martial law. A state of siege is a well recognized condition of society countenanced and carefully regulated by law. The relationship between the military and the civil is well defined - the military is in complete control. Added to this is another factor which makes the handling of riots and disturbances a very easy matter for the French coldier, at least from a legal standpoint. Unlike the United States and England, which are governed by the common law applicable to all persons irrespective of their official position, France has a double system under its droit administratif - the "ordinary" courts and the "admin-

2. 1strative" courts. Under the Frenoh system "no servant of the government who without any malicious or corrupt motive, executes the orders of his superiors can be made civilly responsible for his conduct. He is exempted from the jurisdiction of the ordinary civil courts because he is engaged in an administrative act; he is safe from official condemation because the act complained of is done in pursuance of

1. Decree National Assembly, Dec. 24, 1811 still in operation. 2. Dicey 339 . 
his official duties." He is thus exempt from giving an account of his actions to a civil tribunal even in times of peace. Consider then the power of what would correspond to our military commission operating under martial law- no amenability before a civilian tribunal during or after the siege, and complete power during the siege. The suspension of the law

1. involved in the proclamation of a state of siege is fully recognized by the constitution. It has been said "that the authority of military courts during a state of siege is greater under the Republic than it was under the monarchy of Louis Phillippe." If the Frenchman is unable to cope with riot or insurrection or cannot enforce the law when violence disturbs the machinery of his government, it should not be the fault of the army. The power granted is complete. In time of siege paris is in battle and the contending parties are the army on one side, the malcontents the other and the rules of the game are the laws of war. Contrast this with the situation in a country like the United States or England. Martial law, as 2. such, has not been proclaimed in England since the 
Revolution of 1688. The Riot Act, under which the military acting as aid of the civil authority, may attack mobs not duly dispersing is the chief legislative act on which military interference is sanctioned. By the common law, however, there is a deepor foundation for "martial" law. In England every subjoct whether a civilian or soldier, not only has

1. the right but is as a matter of legal duty bound to assist in putting down breaches of the peace. "The degree of force which may lawfully be used in their suppression depends on the nature of each riot, for the force used must always be moderated and proportioned to the circumstances of the case and the end to be attained. The taking of life ean only be justified by the neceseity for protecting persons or property, or by the necessity of dispersing a riotous crowd which is dangerous unless dispersed."

"Officers and soldiers are under no special privileges and subject to no special responsibilities as regards this principle of the law. A soldier for the purpose of establishing civil order is only a citizen armed in a particular manner ..... To call for 
assistance against rioters from these who can only interpose under grave conditions ought ...... be the last expedient of the civil autroritios. But when the call for belp is made and a necessity for assistance from the military has arisen, to refuse such assistance is in law a misdemeanor."

"The whole action of the military, when once called, ought to be based on the principle of doing and doing without fear, that which is absolutely necessary to prevent serious crime........ No set of rules exists which governs every instance or defines beforehand every contingency that way arise. The question whether on any occasion the moment has come for firing upon a mob of rioters depends ..... on the necessity of the case. Such firing to be lawful ...... must be necessary to stop or prevent........ serious and violent crime.... and it must be conducted without recklessness or negligence. When the need is clear the soldier's duty is to fire with all reasonable caution, so as to produce no further injury than what is absolutely wanted for the purpose of protecting person and property." 
".... The effect of the Riot Act is only to make the failure of a crowd to disperse for a whole hour after the proclamation has been read a felony; and on this ground to afford a statutory justificam tion for dispersing a felonious assemblage even at the risk of taking life..... No justification ..... for firing can ..... be rested on the provisions of the Riot Act itself..... The fact that an hour had not expired since its reading does not incapacitate the troops from acting when outrage had to be prevented.... The justification.... must stand or fall entirely by the common law. Was the act necessary and no more than was necessary to put a stop to or prevent felonious crime? In doing it, did the soldier exercise all ordinary skill and caution so as to do no more harm than could be reasonably avoided?"

"If these two conditions are made out, the fact that innocent people have suffered does not involve the troops on legal responsibility... The soldier who fired has done nothing except what was his strict legal duty."

Thus in England although a state of siege is 
not expressly provided for by law, the right to put the feopie into a state of siege by the establishment of martial law is sanctioned by the common law. The point of difference is that the soldier is his own guide. The mere fact that his actions were in furtherance of martial law is no defense. The things he does that are necessary to establish order may be justified but in the last analysis it is a court and jury that will have the final say as to whether his actions were justified or not.

Here is the other difference between martial law under comnon law and the state of siege under droit administratif. The fixed doctrine of English law is that a soldier, though a member of a standing army is subject to all the duties and liabllities of an ordin1. ary citizen. "Nothing in this act contained", to quote the first Mutiny Act, "shall extend or be construed to exempt any officer or soldier whatsoever from ordinary process of law." A soldier is subject to the same criminal liability as a civildan. The fundamental principle of French law, on the other hand, is that every kind of crime or offense cormitted by a 
soldier or person subject to military law must be tried by a military tribunal. When an English, or for that matter an American soldier, is put on trial on charge of crime, obedience to superior orders will not in itself be a defense. Thus even under martial law if a soldier fires upon a mob or uses wore force than is necessary even though ordered by his superior officer to do so, he is still subject to trial and punishment. Consider the difficulty, then, of the British or American army officer on riot duty. Discipline is the most important element in a military establishment and is what distinguishes it from an armed mob. From the day a man enters the army he is grounded in the fundamental principle of unquestioning obedience to his superior. "Orders is orders" is a maxim known to every soldier. To shoot when ordered is expected of the soldier. To try him for obeying an order undermines. all discipline. No longer will he faithfully obey every order but he will reserve for himself the decision as to whether he thinks the order is a lawful one or not. Consider then what would be the plight of the soldier, who when summoned before a court martial for disobedlence of orders and refusal to shoot when directed, 
woudd argue that he did not think the order was lawful and chose to disobey rather than pay later the penalty for having obeyed an illegal order. The American and British armies both have that factor to consider in their administration of martial law.

1 .

The position of a soldier is curiously illustrated by the following case." $\mathrm{X}$ was a sentinel on board the Achille when she was paying off. The orders to him from the preceding sentinel were to keep off all boats, unless they had officers with uniforms on them or unless the officer on deck allowed them to approach; and he received a musket, three blank cartridges and three balls. The boats pressed; upon which he called repeatedly to them to keap off; but one of them persisted and came close under the ship; and he then fired at a man who was in the boat and killed him. It was put to the jury to find whether the sentinol did not fiee under the mistaken impression that it was his duty; and they found that he did. But a case being reserved, tho judges were unanimous that it was, nevertheless, murder. They thought it, however, a proper case for pardon; and further they were of the opinion that if the act 
had been necessary for the preservation of the ship as if the deceased had been stirring up a mutiny, the sentinel would have been justified."

The important point is that the jury decided in a quiet and deliberate manner long after the act was committed when "peace" had been restored whether the order in question was legal or not; and every soldier in performing his work must always remember the possibility of his being brought before a civilian tribunal to answer for his acts. Placed in such a dilemna, what is from a legal point of view the duty of the soldier? The following answer seems to be as near the correct reply as may be obtainable. It is an opintion of Mr. Justice Stephen.

"I do not think that the question how far superior orders would justify soldiers or sailors in making an attack upon civilians has ever been brought before the courts of law in such a manner as to be fully considered and determined. Provably upon such an argument it would be found that the order of a military superior would justify his inferiors in executing any

1. Stephen, History Criminal Law of England Vol. I, 205-206 
orderw, which they might fairly suppose their superfor officer to have good reason for giving. Soldiers might reasonably think that the ir officer had good grounds for ordering them to fire into a disorderly crowd which to them might not appear to be at that moment engaged in acts of dangerous violence, but soldiers could hardly suppose that their officer could have any good grounds for ordering them to fire a volley down a crowded-street when no disturbance of any kind was either in progress or apprehended. The doctrine that a soldier is bound under all circumstances whatever to obey his superior officer would be fatal to military discipline itself, for it would justify the private in shooting the colonol by the orders of the captain or in deserting to the enemy in the field of battle on the order of his immediate superior. I think it is not less monstrous to suppose that superior orders would justify a soldier in the massacre of unoffending civilians in time of peace, or in the exercise of inhuman cruelties, such as the slaughter of women and children during a rebelition. The only line that presents 
itself to my mind is that a soldier should be protected by orders for which he might reasonably believe his officer to have good grounds. The inconvenience of being subject to two jurisdictions, the sympathies of which are not unlikely to be opposed to each other, is an inevitable consequence of the double necessity of preserving on the one hand the supremacy of the law and on the other the discipline of the army."

There is no getting away from the fact that the British and American soldiers are in a very delicate position in the performance of riot duty and they have to be the most "1ntelligent soldiers on earth". The right to pardon, possessed by all state and national executives, and the crown makes his lot a little easier for the remedy of nullifying an unjust conviction for obedience to orders could always be used. Nevertheless the comon law gives him no exemption from liability on the ground of obedience to orders per se. They must be legal orders.

Here we have then the difference between the continental and English schools. The French soldier 
is supreme in a state of siege. Under the common law the civil law is always supreme. Necessity is the sole justification for any acts of violence. The English and American soldier must always answer before a civil tribunal; the Fronch soldier is judged in his conduct purely by military standards before a military tribunal.

It would seem that the Anglo-Saxon soldier is at a decided disadvantage in dealing with riots or insurrections as compared to the continental soldier even of as democratic a country as France. Nevertheless it will be found that the American or British soldier has acted as promptly and as forcibly as was necessary and his actions have on the whole, stood the test before the civilian tribunal and have been upheld. Wherever force, more than was duly necessary, was employed the soldiers were rebuked and their actions nullified. A notable example of such a case in

1. English history is to be found in the famous Wolfe Tone's case. "In 1798 Wolfe Tone, an Irish rebel, took part in a French invasion of Ireland. The man-of-war in which he sailed was captured and Wolfe Tone was 
brought to trial before a court-martial in Dublin. He was thereupon sentenced to be hanged. He held, however, no commission as an Bnglish officer, his only commission being one from the French republic. On the morning when his execution was about to take place application was made to the King's bench for a writ of habeas corpus. The ground taken was that Wolfe Tone, not being a military person was not subject to punishment by a courtmartial, or in effect that the officers who tried him were attenpting 11 legally to enforce martial law. The Court of King's bench at once granted the writ. When it is remembered that Wolfe Tone's substantial guilt was admitted, that the court was filled with judges who detested the rebels, and that in 1798 Ireland was in the midst of a revolutionary crisis, it will be admitted that no more splendid assertion of the supremacy of the law can be found than the protection of Wolfe Tone by the Irish bench."

Granted that the average court will give the average soldier or officer a square deal when he is called before it to show that the force he employed was necessary and not in excess of the need, that the 
order be obeyed he had every right to believe was lawful and just, what would his natural reaction be? Would he not be likely to shirk responsibility just a bit and be hesitant in his dedisions thus undermining the most important essential of a good military leader? And what is to become of the overzealous soldier, the one who in his anxiety to protect the public oversteps the legal bounds and does a bit more than is absolutely necessary, but yet not in culpable excess; the man who performs a moral duty, his motive being patriotic, unselfish and beneficial to the public, should he be considered a law breaker? If this were the case we would be discouraging a vital factor in the necessary makeup of all good and honest governpent employees. To protect him, therefore, England passes an Indemnity Act. To take an example of one of these "moral" acts. Suppose there was a period of threatened invasion and an army officer without any legal authority arrests and imprisons on suspician a number of men who are regarded as disloyal by $h i m,-$ he may bo performing a moral duty, and if his suspicions were well founded he may have performed a great public ser- 
vice. Nevertheless he neods an Act of Indemnity to protect him.

This, then, is the purpose of the Act of Indemnity not to legalize all military acts committed during a rebelifion, but only those committed through overzealousness which carried a moral obligation though not a legal one. Whatever else is done must be justified by the doctrine of necessity recognized by common law and ultimately settled by judge and jury. The beat thing about an indemnity act is that it works as a sort of vote of credit to the army, though legally it procures little or nothing that the common law does not already give.

\section{II.}

So far we have merely considered the aspects of martial law from an English point of view but what is true of England is in general, true of the United 
States. The law of the land is the English common law in both cases. In the American national and state constitutions we often find written the terms martial law or its existence implied. The English constitution being unwritten recognizes the existence of martial law and even if we found no mention of it in the American constitution judges and juries would have to take cognizance of it by virtue of its existence under the common law. Having written references to it in our constitution particularly emphasizes its existence. The federal constitution provides that the "privilege of the writ of habeas corpus shall not be suspended unless when in cases of Rebellion or Invasion, the public safety may require it". This implies clearly that there are times when the writ may be suspended; and suspension of the guaranteed rights of the individual may clearly be an act of martial law. The Constitution gives Congress the power to provide for calling forth the militia to execute the Laws of the Union, suppress insurrection and repel invasions, clearly providing for military interference in the civil life of the American comrunity. Furthermore we have the provision 
that the "United States shall guaranteo to every state in this Union a republican form of government and shall protect each of them againgt invasions and on application of the Legislature or of the Executive (when the legislature cannot be convened) against domestic violence."

Thus we have clearly provided for martial law in the United states and under these constitutional provisions and similar ones, found in all state constitutions, for civil appeal for military intervantion. Whenever the question has come before the supreme Court of the United States that judicial body has always recognized the right to establish martial law as existing for both federal and state governments. It has often declared itself against some particular act of a military person in the execution of martial law but never against the principle. In one of the first 1. cases to come before this tribunal, that of Luther ve Borden, the Supreme court said in part: "Unquestionebly a state may use its military power to put down an armed insurrection too strong to be controlled by the civil authority. The power is essential to the existence of

1. Luther vs Borden 7 Howard I, (1848) 
every government, essential to the preservation of prder and free institutions and as necessary to the States of this Union as to any other government. The state itself must determine what degree of force the crisis derands, and if the government of Rhode Island deemed the armed opposition so formidable and so ramified throughout the state as to require the use of Its military force and the declaration of martial law, we see no ground upon which the court can question its authority". Occasionally we find some court which does not subscribe entirely to these tenets but these are exceptional.

As for the question of responsibility of subordinates for illegal orders executed in obedience to military superiors, American courts have handed down some interesting decisions which in the wain, uphold the common law doctrine.

1. In the case Commenwealth vs Blodgett, the supreme Court of Massachuisetts said in part: "It has been argued upon the grounds of the evident hardships of the case that men ought not to be held responsible for acts done in obedience to order which they are compell- 
ed to obey under severe military discipline. But this is not the true principle and it would be dangerous in the extreme to carry it out into its consequences. The more general and the sounder rule is that he who does acts injurious to the right of others can excuse himself as against the party injured by pleading the lawful commands of a superior whom he is bound to obey. A man may be often so placed in civil life and more especially in military life, as to be obliged to execute unlawful comands on pain of severe legal consequences. As against the party giving such command he will be justified; in foro conscientiae he may be excusable, but toward the party injured the act is done at ris own peril and he must stand responsiblen.

Thus we find American and Inglish law in accord. Both recognize the existence of martial law. Both hold the subordinate responsible for obedience to unlawful orders. Both agree that the necessity for martial law and the extent of its operations are in the last analysis decided by a coutt. 


\section{III.}

We now come to consider the operation of martial law. We find that although the theories of martial law in England and the United States are about the same, the circumstances under which martial law has been instituted vary appreciably between the two countries. English cases of the last century are nearly all confined to her colonies or. Ireland, while mast of our cases refer to continental united States.

Our chief interest is in the operation of martial law in the United States. Passing briefly over the most prominent English examples will be sufficient to show that "peace does not always reign in the King's realm" - the scenes attending the seating of Mr. Wilkes in Parliament in 1768, the Gordon riots of 1780 , the Manchester riots of 1830 and the many examples in Ire-

1. land, particularly the experiences of 1920-2l. Witness also its exercise in Jamaica in 1867, when 354 persons were put to death under sentence of court-martial and 85 persons without tpial; 600 persons, some of whom were women, were flogged and imprisoned and 1000 dwell- 
ings were destroyed by burning- all by way of punishment of alleged rebels and within a period of one month. Outside of placing the governor of a colony in a situation analagous to a governor of a state in our country in reference to the power to declare martial law, English colonial experience offers nothing more of particular interest.

We now come to a consideration of martial law in the United States. We are particularly interested in the cases of the last fifty years, or the period when the United States has been emerging from an agricultural into an industrial state. These years also mark the great flood of foreign elements into this country, which play a very important part in the labor and strike movements. Although most American cases involving the exercise of martial law are of relativeIy recent origin, we find it exercised in the period of infancy of the American republic. Even before the

1. Declaration of Independence in 1775 we find martial law in this country. In June of that year General Gage commanding the British forces declared martial 2. Law in Boston; and in November of the same year Gov- 
ernor Dunmore establishei martial law in Virginia. Our forefathers were highly sensitive about the exercise of martial law and they denounced the action in Boston as an "attempt to supersede the course of the common law and instead thereof, to publish and order the use of martial law". The Virginia assembly

1. in equally vehement tone denounced Governor Dunmore's act as an "assumed power which the King, himeelf cannot exercise; because it annuls the law of the land and introduces the most execrable of all systems, martial law".

2. About ten years after Massachusetts had denounced the action of General Gage it was compelled to declare martial law ob its own accord, November 10, 1786. The General Court (i.e. the legislature) suspended the privilege of the writ of habeas corpus at the same time empowering the governor and council to bring about the arrest and imprisonment without bail of anyone whom they considered dangerous to the Commonwealth. This took place during the famous Shay's Rebellion. The first instance of the employment of federal troops enforcing the law we find in the Whiskey Insur- 
1.

rection in Western Pennsylvania, 1794-5. No suspension of the writ was resorted to although insurgents were arrested by military authority. They were tried, however, by civil courts. There were several important precedents established by this case. The first question involved the power of the president to call out troops. Congress had passed an act February 28, 1795, authorizing the president under certain circumstances to call

2. out the militia. The law was upheld by the courts, and the president was held to be the final judge of the emergency justifying such a call. Another precedent established at this time was the formal proclamation of martial law. As a condition precedent to the employment of military force the president is required now by proclamation "to comand the insurgents to disperse and retire peaceably to their respective abodes within a limited time". (Sec. 5300 Revised Statutes.)

3. Legally the proclamation is not required. "The proclamation of martial law does not, unless under some statutory provision, add to the power or right inherent. in the government to use force for the repression of disorder, or for resistance to invasion. It does not

1. Winthrop 828

2. Martin vs Matt 12 Wheat 19

3. Dicey 510 
confer upon the government any power which the government would not have pessessed without it. The object and effect of the proclamation can only be to give notice to the inhabitants of the place with regard to which martial law is proclaimed, of the course which the government is obliged to adopt for the purpose of defending the country or of restoring tranquility". In American practice proclamations have usually been issued. The instructions of President Washington to 1. the troops are also very significant. He said in part: "Every officer and soldier will constantly bear in mind that he comes to support the laws and that it would be peculiarly unbecoming in him to be in any way the infractor of them; that the essential principles of a free government confine the province of the military, when called forth on such occasions to two objects: first, to combat and subdue all who may be found in arms in opposition to the national will and authority; secondly to aid and support the civil magistrates in bringing offenders to justice. The dispensation of this justice belongs to the civil magistrates, and let it ever be our pride and glory to leave the sacred deposit there inviolate." 
IV.

The first case to command our attention from a military point of view involving the exercise of authority upon the initiative of a military commander took place in New Orleans in 1806. Burr's conspiracy which loomed up as a serious factor, menacing even the inte-

1. grity of the Union, was based on the sentiment aroused in the West against the Federal Union. The most alarming rumors had reached New Orleans. General Wilkinson in cownand of the Western Department declared martial law. The militia was placed under Wilkinson's command and numerous volunteers offered their services. Wilkinson who seemed to know all the machinations of the conspiracy took the initiative in his own hands and employed the means at his disposal, that he regarded absolutely necessary for the safety and wellbeing of the country. He placed under military arrest Dr. Bollman. Messers Swartout and Ogden, Burr's emissaries. Wilkinson's connections with the whole affair did not 2. seem to be entirely above board and there is some evidence that Burr had expected his assiscance. Modern 
historians have accused him of even receiving a bribe from Spain to betray Burr. Anyway, he arrested the men in question, who had been acting for Burr. Bollman was immediately brought before a judge of the Superior court by a writ of habeas corpus and Wilkinson returned to the writ that what he had done had been necessary for the safety of New orleans, and that he would continue to arrest dangerous persons. Other arrests took place and some very sharp contests developed between the military commander and the members of the judiciary. In one instance, he confined not only the counsel for the prisoner but the judge who issued the process. His performance was nevertheless upheld by the Chief Executive, for President Thomas Jefferson, as soon as the news reached him, issued a proclamation directing the employment of the regulars and militia to sieze very man and thing connected with Burr's conspiracy. The senate too, became hysterical and one of its first acts after convening in 1807 was to pass a bill suspending "the operation of the writ of habeas corpus for three months in cases of arrest for treason or for other acts en- 
dangering the peace or neutrality of the United States". The House rejected it. Bollman and Swartout, the accused conspirators, had been sent to Washington to be tried before the Supreme Court of the United States. Chief

1. Justice Marshall discharged them on a writ of habeas corpus. In passing upon this question Chief Justice Marshall expressed incidentally the opinion that the suspension of the writ was a power to be exercised by the legislature. This dietum led to a great deal of discussion during the period of the Civil War. Thus in the first exercise of discretionary power the military received somewhat of a rebuff. General Wilkinson had, it seemed, overstepped the bounds of absolute necessity when he in fact susfended the writ of habeas corpus.

About teh years later a similar drama was played in the city of Now Orleans with different characters. 2. Major General Pakenham in command of the British force had been threatening to capture the city of New orleans. General Jackson did not have sufficient troops to defend the city, and he issued the following order - "All able-bodied men, of whatever race, color, rank or con-

1. Ex Parte Bollman \& Swartout 4 Cranch 100

2. Winthrop 822 
dition are compelled to serve either as soldiers or sailors". The situation was indeed a critical one, particularly since the city of New orleans contained a large foreign element, principally French, who were not in entire accord with Jackson. On Narch 16, 1814, he issued the following proclamation: - "Major General Jackson comanding the seventh U.S. Military district declares the city and environs of New Orleans under strict martial law, and orders that in the future the following rules will be rigidly enforced, viz: Every individual entering the city will report to the adjutant general's office and on failure to, be arrested and held for examination. No person shall be permitted to leave the city without permission in writing, signed by the general or one of his staff. No vessels, boats or other craft will be permitied to leave New Orleans or Bayou st. John without a passport in writing from the general or one of his staff or the commander of the naval forces of the United states at this station. The etreat lamps shall be extinguished at the hour of nine at night after which time persons of every description found in the streets or not 
at their respective homes without permission in writing as aforesaid and not having the countersign shall I. be apprehended as spies and beld for examination". In the face of an impending orisis General Jackson had declared martial law and as long as the British forces were at the gates of the city his power or authority seems never to have been questioned by the civilian population. The necessity for extreme measures existed and was recognized. January 19 the British retreated to their fleet. To many of the civilians it seemed as though the crisis had passed. To be sure they possessed no expert knowledge, such as was available to the military commander. The official news that peace had been doclared did not reach New Orleans until March 13 and it was during this interim between January 19 and March 13 that the clash betwoen the military and civilian authorities took place. 2. Rumors of peace had been floating in the atmosphere of New Orleans from the day the Britigh fleet had departed. Many of the soldiers impressed for the. emergency were anxious to be released from the military service. One Livingston, aide to General Jackson, ro-

1. Parton Life of Jackson

E. Parton - Iife of Jackson 240-8 
turned to New orleans after a trip to the British fleet under a truce with the news of peace, February 19. The troops expected their release at this time but the report was merely a newspaper clipping, which, of course could have no bearing on Jackson's attitude. He had no reason to believe that it was not a clever ruse on the part of the British to spread dissension in his ranks. From a military point of view, he might have been severely reprimanded for the premature discharges of the only men he had at his disposal. Jackson attempted to vindicate his ections by proclamation but the city became ven more infuriated at him. The Louisiana Gazette, on February 2l, published a news item to the effect that peace had been announced. Jackson prepared an official contradiction which the same paper was ordered to publish, but it had no effect on the prevailing sentiment.

At this stage some of the French troops hit upon an expedient to escepe from the service by claiming the protection of the French consul. Foreign as well as naturalized Frenchmen plead the same exemption. Jackson, thereupon ordered the consul and all frenchmen who were 
not citizens, to leave New Orleans in three days and not to return within one hundred and twenty miles of the city until the news of the ratification of the treaty of peace was officially published. Jackson consulted the register of voters of the last election and insisted upon holding those Frenchmen who voted, as "fellow-citizens", and they were compelled to remain with the colors until the emergency was over. The Louisiana Courier printed an article by Louis Louailier, a citizen and member of the legislature, which remonstrated against the order banishing the French population from the city. General Jackson arrested and confined Louaillier. When Judge Hall of the U.S. district court granted a writ of habeas corpus directing the General to bring the prisoner before the court to be dealt with in the legal manner, General Jackson arrested and confined the judge for a week. Louiallier was charged with mutiny and libel among other charges and his case was to come up before a court martial. The judge was accused of aiding and abetting the enemy in "my camp" - to quote the General. Other arrests followed, Jackson maintaining that every man in the city was a soldier and New orleans a camp, 
with him in command.

Jackson had some reason to believe that peace had been declared but his information was still unofficial. On Warch 11 he banished Judge Hall from the city and had him freed. March 13 came the official announcement of peace. Louallier was set free and Judge Hall returned. The troops were discharged. The judge ordered the General before the court, adjudged him guilty of contempt, and fined him one thousand dollars, which Jackson paid.

General Jackson evidently was not greatly perturbed over the rebuke he received from the Louisiana court for in 1821 we find him disregarding a writ of habeas corpus again. This occurred in Florida and the General had refused to honor a writ for the benefit of Colonel Collava, the former Spanish Governor of Fensacola, whom he had arrested and confined. (Parton - Chapter XIV.)

There was such divided feeling in New Orleans in reference to the General's administration of the city during this troublesome period that it is difficult to state whether he usurped any power or was 
merely pursuing the necessary means to keep the army intact during the crisis. The test, of course, was met by the court. In this case, being up before the same judge whom he had banished, he probably did not receive the fair and unbiased verdict that the military commander would have received under similar conditions. An attempt was made to vindicate General Jackson by an act of Congress of February 16, 1844, nearly thirty years latẹ, by refunding him the fine with interest. The act passed, but it was based part-

1. ly on party lines. The senate passed the act 28 to 20; the House 158 to 28 .

With the exception of the famous luther vs Borden decision handed down by the supreme Court in 1848, nothing of any importance in connection with the use of the military organization in maintaining peace in the United States took place until the Civil War. Outside of clearly defining the meaning of martial law in this case, which arose as a result of

2. the Doerr rebelition in 1842, the supreme Court held that a state may, when the public safety demands it, proclaim martial law within its own limits, without

1. Parton - 317

2. Luther vs Borden - 7 Howard 1 
infringing upon the United States constitution by exercising war powers delegated to Congress.

\section{V.}

We now come to the Civil war cases and we are concerned here primarily with the cases that developed in the states that remained in the Union. The exercise of martial law by the Confederate states over the seceding states is also of great importance, for it shows how a nation fighting for its existence must employ extreme measures even in the case of its own citizens.

The first question that the Civil War gave rise to was the authority of the presicent to proclaim martial law independent of Congress. Chief Justice Marshall's opinion that the power was lodged in the legislature had never been questioned, and in the leading case of

1. Ex Parte Merryman, Chief Justice Tanney held to the 
same opinion. The president, nevertheless, continued to proclaim martial law whenever he deemed it best for the welfare of the country.

April 29, 1861, President Lincoln had suspended the writ of habeas corpus between Washington and Philadelphia, thus bringing Maryland under military rule. One Merryman of Maryland was arrested by military authority and when Chief Justice Tanney called upon General Cadwallader to deliver the prisoner ho was refused. The question was brought before the Attorney General by the president and the President's power to declare martial law and suspend the writ was

1. upheld, which Chief Justice Tanney denied. In 1862 President Iincoln suspended the writ in the District of Columbia, and other parts of the country for men who were rebels, insurgents, aiders ar abettors of the same in the United states, those discouraging enlistments, resisting the draft, aiding the enemy and subjected them to martial law. On september 15, 1863 a proclamation was issued extending the suspension to all persons so engaged anywhere in the country. In 1864 the president made a similar pro-

1. Carpenter Military Government Southern Territory, American Historical Assn. 1900, Vol. 1 471-498. 
clamation in the case of Kentucky. This power of arrest was first exercised by the state department alone, then concurrently with the War Department and finally by the latter exclusively.

The first case of bloodshed and one of the most interesting developments in the administration of mil-

1. Itary power over a "loyal" civilian population took place in BaItimore. As early as March 18, 1861, the Confederacy had opened a recruiting station in the city

2. and many men were obtained for the South. April 19, 1861, the Sixth Massachusetts Regiment armed with rifles was passing through Baltimore enroute to Washington and was violently attacked by a mob. The mob was first to fire and one soldier in the ranks was killed by a pistol shot. The order to fire was given the troops and

3. it was executed. Four soldiers, many members of the mob and one innocent on-looker were killed. The mayor of the city placed himself at the head of the column and begged Captain Follansbee in command of the company not to fire any more. In spite of his exhortations to the mob the firing continued into the ranks and finally

1. R.R. Series 1, Vol. 1, page 276

2. Rhodes III, 362-5

3. R.R. Series, L, Vol. II, page 7 
the exasperated mayor seized a soldier's musket himself and killed a man. The soldiers then fought their way through the mob and finally reached the Baltimore and ohio depot where they took the train to Washington.

Immediately after this attack Butler was appointed to command the city and the neighborhood. This territory was under martial law by the president's proclamation of April 29, and the army was therefore in control. When General Banks took command he appointed a provost marshal for the state and wade all police officers subordinate to him. The result was that the police commissioners of the city ordered the disbandment of their force. The commissioners were then arrested and a new force established. September 12 an order as issued for the arrest of all members of the legislature who were suspected of sympathy with the South.

The trouble between the army and the police came up over the question of arms. General Banks accused the police of not only having full cognizance of the stores of hidden ammunition but of protecting 
1. those engaged in their distribution. Police headquarters was virtually an arsenal. In defense of the police commissioners it must be said that arms were needed for their own purposes and without them the mob might have proved more than a match for the Massachusetts Regiment, that passed through in April. The General promised not to interfere with the municipal government any more than absolutily necessary.

In Missouri we find a parallel situation. Divided sympathies betwoen the North and South within the state required strength and energy to prevent it from partly aiding the confederacy or deserting 2. the federal cause entirely. On July 31, 1861, General Pope gave orders that every county seat and town of any size in Northern Missouri would be visited by a military force and in each a responsible committeo of public safety was to be appointed. These bodies were to maintain peace and order and if they were unable to do so the military forces would take complete charge and administer the service at the expense of the county.

Disorder was $r$ fe in Missouri and in the mid3. st of uncertainties General Fremont declared martial

3. Carpenter 474 
Iar August 31, 1861, in these terms: "Circumstances in my judgment of sufficient urgency render it necessary that the commanding General of this department should assume the administrative powers of the state....... The object of this declaration is to place in the hands of the military authorities the power to give instant effect to the existing laws and to supply such deficlencies as the condition of war demands."

This order was is sued upon the general's orm initiative and moant that in all cases the military 1. commander would really be the ultimate judge. August 30 Fremont issued from his headquarters at St. Louis a proclamation confiscating the property of all persons in the state ..... "who shall take up arms against the United States or who shall be directly proven to have taken an active part with their enemies in the field and declaring their slaves free men". He then set up a bureau of abolition and issued deeds of manumission to slaves. President Lincoln revoked the references to freeing of the slaves. Here we note a check upon the arbitrary power of a military commander, which is too often overlooked- his responsibility to 
his superior. The military commander not only has the liklihood of being brought before a civilian tribunal after the exigency has passed but of being taken to account by his superior at any moment.

The military authorities were in a constant struggle with the civilian population of the state over 1. the question of freedom of the press. On January 9 , 1862, the provost marshal ordered all newspapers in Missouri, st. Louis excepted, to furnish him a daily copy for inspection upon pain of having their papers suppressed. A strict censorship of the press was undertaken. The War Bulletin and the wissourian, pubIished in St. Louis, were suppressed for making false statements about military movements. May 11 the sale or distribution of the New York Freeman's Journal and the Caucasian, the Columbus Crisis, Chicago Times and Daily Herald was prohibited.

People were forbidden to move cut of the county without a permit, ministers of the gosfel were interered with, and property of all sorts was confiscated. At one time in St. Louis General Halleck ordered that the president, secretary, librarian, directors and other 
officers of the Mercantile Library Association; president, secretary and directors of the Chamber of Commerce should resign if they failed to take the oath and any attempt to exercise their office was to be severly punished. The officers and professors of the State University received the same order. Mayors, judges and state officials were removed and others put in their places. Supervision was exercised over all courts. Dr. McPheeters, a clergyman was removed from his church because he had a rebel wife, rebel relations, and expressed rebel sentiments. The president and directors of railroads in st. Louis had to file bonds that they would employ only Union men. An at tempt was also made to control labor's dictates to capitol. NNo person was to hang around or annoy employees, nor was any association to dictate to the proprietors" of certain factories. In October, 1864, it was declared that voting contrary to orders was a military offense. Kentucky's experiences were very similar to 1. those of Maryland and Missouri. "Arrests were carried to great lengths in 1864 when both civil and judicial officers incluaing the Lieutenant Governor, the Chief

1. Carpenter 476 . 
Justice, together with the delegates to the Chicago convention were placed in confinement. At Henderson, Kentucky, July 28, 1863, an order was issued ordering army officers to see that none but loyal persons either acted as election judges or voted, and that no dislojal person was a candidate.

Thus far we have considered the operation of martial law during the Civil War in the border states contiguous to the field of operations and in the imediate vicinity of the battlefield. Strict measures had to be taken and the commanders did what they deemed best for the welfare of the Union cause. Military authorities were mixed into civilian affairs in other parts of the North as well as in the border states. The most important cases were found in Ohio and New York. The work of the army in the first case is ratber questionable but in New York the army was the factor that aved millions of dollars and probably thousands of lives. After General Burnside was assigned to command the Department of Ohio, he issued on April 13, 1863, his famous General order 38, which said in part: "the habit of declaring sympathy for the enemy will not be allowed in this department .... It is distinctly understood 
that treason, express or implied, will not be tolerated". Soon another order followed which said that the publication and circulation of books containing sentiments of a disloyal tendency were to be considered in the same category. In May of this same year, Vallandigham, a member of Congress who was a candidate for state governor, made a speech at Mt. Vernon, Ohio, criticising the course of the administration. While there was nothing of a dofinitely hostile nature in his speech it went as near giving aid and comfort to the rebellion as any taik could that proceeded from a "good lawyer who knew the law". General Burnside had two plain clothes men, army captains, in the crowd, who took notes on the speech. Their report to the General prompted him to send out a company of soldiers to bring Vallandigham to Cincinnat1. They arrived in Mt. Vernon after midnight, forced their way into his house and carried our their orders. The General refused to recognize the writ of habeas corpun, had Vallandigham tried by a military tribunal which found him guilty and sentenced him to close confinement for the duration of the war. The president approved Buraside's action but commuted the sentence to banishment from the Union and he was sent South. This incident 
took place many miles from the roar of cannon and field of battle and yet the action was justified as a military necessity, although the doctrine established was overthrown by the Supreme Court in 1866 in the Miligan case. The justification for such an act is most clearly expressed in President Lincoln's own

1. words: Must I shoot a simple minded soldier boy who deserts, while I must not touch a hair of a wily agitator who induces him to desert? This is none the less injurious when fected by getting a father, or brother or friend into a public meeting and then working upon his feelings till he is persuaded to write the soldier boy that he is fighting in a bad cause for a wicked administration, too weak to arrest and punish him if he shall desert."

In New York city it was the civilian population that cast the law aside and took matters into its 2. own hands necessitating milltary interference to insure order and peace. The Conscription Act of March 3, 1863, began to operate in New York City July 11, and a riot broke out. The objection to the draft seemed to have been caused by the clause allowing persons to

1. Rhodes IV, 250

2. Ibid, IV $-324-8$ 
get a substitute for $\$ 300$. The poorer classes consisting principally of foreigners objected to this discrimination in favor of the rich, as $\$ 300$ was quite a large amount at this time. There were very few troops in the city and this gave the lawless elements an opportunity to plunder and destroy property. A worse case of vandalism had never exhibited itself before in the history of the country. The anger of the mob directed itself not only to the rich but to the colored peoplethe cause of it all. A race riot such as the south never heard of followed. There was a great deal of bloodshed. The harbor defenses were stripped of practically all the soldiers and marines to quell the disturbance. The Seventh Regiment, New York's own which was in Maryland, was rushed back to the city. Troops arrived from Pennsylvania. For four days the soldiers fought the frenzied mob and finally peace was restored but not until the riot took its toll of about one thousand killed and wounded to say nothing of the destruction of property valued at over one and a half million dollars. Following this affair ten thousand infantrymen and three batteries of artillery were detached from the army of 
the Potomac and stationed in New York city.

Thus we find the Union exercising force whenever the situation demanded it. In time of war we must be a nation in arms and every individual a part of the "army" whose hearty cooperation is necessary for the good of the cause.

The south, too, found it necessary to combat disloyalty in its own ranks, and Jefferson Davis and the Confederate Generals were on many occasions called upon to suspend the writ of habeas corpus and declare friendly territory under martial law. A letter from J.A. Campoll, the acting secretary of War, in reference to declaration of martial law in Atlanta expresses the attitude of the south on the whol subject. This letter is written to Major General Samuel Jones dated October 1. 27, 1862, at a time when the southern prospects of victory were very bright. He said in part: "the proclametion of martial law in a locality implies that the district is the seat of war or that it has or may soon fall within the lines of military operations or communication. It implies that a more vigorous policy has become necessary to preserve the efficiency of the army and to

1. R.R. Series I, Vol. XVI, Part II- 979 et seq. 
maintain its diseipline, to secure in all its fullness its energy and vigor for use against the enemy or it may imply that such an emergency has arisen as to require an extraordinary application of the resources of the population for their defense.

The system of measures and administration which is introduced in such extraordinary and transitory exigencies involving the public safety is perhaps inaptly called martial law, for the measures and administration vary according to circumstances and are occasional and transient in their operation as to time and limited as to locality, seldom proceeding from the supreme power of the state or affecting the constitution of the body politic, not often necessarily impeding municipal administration.

A city, the capitol of a state or nation, the depository of its government and archives, the site of its workshops, arsenals, hospitals, magazines, and munitions with an insufficient army for its defense, and a wavering population beleagured by a powerful and bitter enemy who could make its goods a booty and its house a desolation surely must be subject to conditions as to government and police dissimilar from that of a city 
sheltered against danger from any quarter.

These regulations not existing, but called for by such extraordinary circumstances find their authority in this Confederacy in the commission of the Executive to use the military force of the nation to repel invasions and adopt the measures requisite to employ this force with the utmost advantage for that end. In the fulfillment of this office he may not make unreasonable or vexatious searches and seizures nor unduly restrain liberty or take life, but the same act may be reasonable at one time and under one class of circumstances and be vexatious and unlawful under another.... military administration- must have a liberal extent..... In so far as it affects citizens who do not belong to the army it should be marked with sobriety, discretion and deference for personal rights. The objest of the proclamation in Atlanta was to secure the safety of the hospitals, public stores, railroad communications, the discipline of the troops in transitu and to collect deserters and absentees along the railroae and guard against espionage on the part of the enemy ..... Some regulation of that 
unlimited freedom of intercourse and traffic which exist in time of peace has been found to be proper and some appropriation of private property for public use essential."

We need not concern ourselves with the cases that arose during the Union occupation of Confederate territory during the war as the South's claim to belligerent rights had been recognized and consequently the international law dealine with the occupation of enemy territory covers those cases. The cases of the Reconstruction period in many instances resemble the laws executed over conquered territory and not as a purely domestic affair, and we can readily pass over them.

VI.

The next landmark in the operation of martial law in the United states is to be found in the strikes of 1877. Before taking up the strikes of 1877 let us consider two important incidents that took place in the 
1. intervening ten years. In March, 1867, the Tennessee River overflowed in Chatanooga imperilling life and property and calling for Unusual precautions for their protection. At the request of the civil authorities Capta in J. Kline, 25th Infantry, commanding the post placed the city under martial law and directed the seizure and use by the army of boats for the purpose of moving household goods. His actions were very praiseworthy and he was commended by the mayor in these terms: Martial law under ordinary circumstances is distasteful to a people inclined to the pursuits of civil life; but your action in this case must meet the commendation of all right thinking poople."

2. The other important incident of this period was the proclamation by the President on October 17, 1871, during the famous Ku Klux KIan disturbances suspending the writ of habeas corpus and virtually initiating martial law in certain countios in South Carolina. Tho moral effect of the mere presence of troops on this occasion, as well as in many others, proved sufficient 3. to maintain order. For the year 1872 there was only one case of bloodshed and that was justified by a coroner's

1. Winthrop 827

2. Winthrop 828

3. Report Sec. War 1872 
jury. In all others the deputies had no trouble arresting offenders.

1.

The use of the army in suppressing illicit distilleries occurred many times during this period.

2. The army also found itself a humanitarian agency in assisting in the distribution of donations for the residents of the $D_{\theta}$ partment of the Platte, who had become destitute because of the grasshopper ravages. The strikes of 1877 afforded many lessons for the future military policy of the United States in handling internal troubles. At Martinsburg, Test Virginia, the first act in this terrible drama was played. Following closely upon severel years of great depression in the raflroad circles due to severe cutthroat competition between the various lines, an agreement was reached among the road presidents in regard to rates and wages and the first step in this direction was a ten percent reduction in the wages of the employees.

The order reached Martinsburg July 16 and the firemen quit work. Soon they induced others to follow. No trains were allowed to pass. Freight was stopped. 
The strike extended along the railroad line. Pretty soon the strike became a riot. The Governor called out the whole military force of the state, which consiated of three volunteer companies, but they were unable to cope with the situation and the President was called upon for aid. The President issued the usual proclamation and then he sent 250 regulars to the scene. Their mere presence was sufficient to disperse the rioters and order was restored.

This incident, however, did not end the troubles on the Baltimore and Ohio railroad. Cumberland, Maryland, a station further west had a similar scene. The railroad company called on the Governor of Maryland for aid. On July 20 he issued a proclamation and mobilized the Fifth and Sixth regiments. When the Fifth reached the depot it was attacked by a mob. Stones were thrown and shots fired into the ranks. The mob became very menacing and the Mayor of Baltimore suggested to the Governor the inadvisability of sending any troops away at such a critical moment. The Governor then revoked his order. The Fifth falled to hold its own at the depot and was on the point of being 
overpowered by the mob when the governor sent three companies of the sixth to its rescue. These companies no sooner left the armory when they were assailed and flred upon. They numbered but about one hundred and twenty while the mob consisted of about four thousand. The militia apened fire without orders and continued firing, kflling nine rioters and wounding seventeen others. The mob was now in a frenzy and assailed all persons in army uniform. Many of the soldiers changed to civilian clothes to escape the mob. By the time the soldiers reached the depot their numbers had been greatly depleted. The mob then attempted to burn the depot. The police rushed to the protection of the militia. Incidentally the entire militia force of Maryland at that time was 725. The Governor called upon the President, and General Hancock was sent to Balti1. more. It is interesting to note that artiliery companies formed the nucleus of Hancock's forces for ordinarily it is the infantry and cavalry that are alIotted such tasks. The presence of the regular troops brought the rioting to an end.

The other center of trouble in 1877 was Penn2. sylvania. Before taking up the. use of the army in 
Fennsylvania, the following factors should be considered: first, the entire regular army consisted of 24,501 men: second, detachments were employed to maintain order in Louisv1lle, Newport Barracks, Indianapolis, Jeffersonville, Galveston, St. Louis, Chicago and New York and other places besides those already mentioned, and third, that during the entire period

1. the regular army was assailed by a mob but once and that in Johnstown, Pa. where there is evidence that it was made in ignorance of the identity of the national troops, and finally, that wherever the regular troops appeared order was at once restored without

2. bloodshed and it was said, "that the rioters feared one federal bayonet more than a whole company of militia". President Hays in the review of the work 3. of the army during the year wrote in his diary: "The riots- not a man shot but order pronptly and firmly upheld."

Incidents in Pennsylvania gave the state militia of 1877 the real test of its ability to maintain order in an emergency. The troubles in Pennsylvania began in Pittsburg. The Pennsylvania Railroad

1. Report Sec. War, Mc Crary 1877

2. Rhodes VIII- 47

3. Ibid VIII- $47 \mathrm{n}$ 
had made two reductions in the wages of its employees since the panio of 1873. A committee of engineers had called upon Thomas A. Scott, the president of the railroad and were apparently convinced that a reduction was inevitable. The other trainmen were not so ready to acquiesce and were in a discontented mood when the company decided to run double headers. A double header means two locomotives, a langer train and the saving of an additional freight conductor, flagman and brakeman- seemingly a practical principle of economy. This caused even greater dissatisfaction. When the 8:40 A.M. train was ready to depart the two brakemen and flagman refused to go out on their double header. Other trainmen refused to take their places. The digpatcher picked up a crow in the yard but they were prevented from making up the train by the strikers. The latter numbering but twenty-five to thirty took possession of the switches and as each train came in enlisted into its ranks the various freight crews. From this inauspicious beginning the strike spread to all railroad employees in Pittsburg. The Superintendent-sought police protection but the mayor, evidently sympathetic toward the strikers, maintained 
that he had no men available. The superintendent then enIisted a number of former policemen and took them to the station. On the way he was attacked. His efforts to get police protection were of no avail.

He then sought the county sheriff, who finding himself unable to hande the situation telegraphed to the Governor for aid. The Governor was beyond the limits of the state but his Adjutant General ordered General Pearson; whose headquarters were in Pittsburg, to call out his tróops and take command. The General ordered out three regiments and a battery. One regiment of 225 answered the call. The others assembled very slowly and it became very evident that their sympathies were with the strikers. General Pearson called to Harrisburg for more help and Nation Guard troops from PhiladeIphia were sent to Pittsburg. Pearson's Pittsburg troops were all fraternizing with the strikers.

The trip from Philadelphia to Pittsburg was badly managed and when the Philadelphians arrived they were hungry. Their fare for the entire trip had been coffee and sandwiches, served but twice on the whole trip. The Philadelphia troops, tired and hungry, were 
imwediately called into action. They marched to the 28 th street crossing where they found the Pittsburg militia fraternizing with the mob. They were ordered not to fire except in self defense. The rloters began to pre thoir ranks and the troops formed a hollow square for defense. A bayonet charge wounded many of the mob and exasperated the rest, who begen to throw missiles at the soldiers. Soon the nob firsa into the ranks. Further emboldened, they tried to wrest the guns from the soldiers. The soldiers began to fire without orders and in spite of the officers' attempts to stop them. At least sixteen of the rioters were instantly killed and many others wounded. The newspapers favoraule to the strikers denounced the actions of the soldiers.

The Philadelphia troops bravely held their ground but expected reinforcements never arrived. The Pittsburg militia had diseppeared from the scene entirely- the struggle was now between the mob and the Philadelphia soldiers. About dusk the soldiers withdrew for rest and food to one of the round-houses. The house was soon besieged. The troops were without food. The provisions, destined for them were seized 
by the mob. Volley after volloy was fired into the round-house. Finally the torch was applied. The sold-

1. iers were passing through a terrible ordeal. "Tired, hungry, worn out, surrounded by a mob of infuriated men, yelling like demons, fire on nearly all sides of them, suffocated and bIinded by smoke with no chance to rest and little knowledge of what efforts were being made for their relief, with orders not to fire on the mob unless in necessary self defense, the wonder is that they were not totally demoralized; but the evidence of all the officers is that the men behaved like veterans."

The dregs of society were now in control of Pittsburg. It was a riot, no longer a strike. E reign of terror followed of fire, plunder and pillage. The troops finally abandoned the round-house and retreated suffering many casualties. The riot died out of its own accord. Order was finally restored through the action of the city authorities, civilian volunteers and a few of the loyal pittsburg militia. The damage was over three million dollars.

The Governor returned at this time, called out ture appointed to investigate Riots 1877 
the entire militia and appealed to the president for aid. He responded. Philadelphia was made the mobilization point and General Hancock arrived there in person at the same time ordering out the entire military forces of the Atlantic. Governor Hartranft started from Philadelphia to Pittsburg, gathered soldiers on the route and arrived in Pittsburg with 4000 men. In adition Fancock sent down 600 reeulars. The riots in Pittsburg ended:

In Reading a similar performance took placethe militia men attacked, firing into the mob, a reign of terror and the final culmination of the riot upon the appearance of regulars, - this time 200 in number. Wilkes-Barre, Scranton and Easton had simflar scenes. The riots of 1877 are the best arguments for a strong militia and the need of an efficient regular army large enough at least to handle similar situations.

The year 1877 also witnessed a great antiChinese uprising in San Francisco, but it is not until 1886 that we get the use of troops to suppress these riots. 
The use of troops was further complicated during the chinese troubles by the fact that these uprisings took place in a territory. In 1856 an uprising had taken place in the territory of Washington and the Governor, a presidentail appointee, proclaimed and enforced martial law. The Governor's authority was questioned and the Attorney General's opinion denied the authority on the ground that the Governor, being an appointee of the president, had only those powers which statutes expressly "gave him. It was admitted that occasions may arise in the history of a territory when it would become necessary to proclaim and enforce martial law, but in such cases the legislature alone had the martial law power. The opinion, of course is legal but on the doctrine of necessity it is questionable whether there will always be an opportunity to call a session of the legislature.

In 1885-6 Washington, still a territory, was the scene of illegal uprisings against the Chinese. Tacoma and Seattle were the centers of hostility. Riotous assemblages became a common occurence. The rioters were armed and defiant of the law. The militia was called but it failed to establish order. The governor 
called for a posse comitatus but it, too failed to get the desired results. The proclamation of the Governor to the mob to disperse was 1gnored. A conflict followed and several persons were killed. The Governor issued a second proclamation and then put Seattle under martial law. Before taking this step the Chief Justice and the United States attorney of the Territory were consulted and they earnestly advised the measure. When the news reached the president he not only approved but ordered General Gibbon to the scene. Two weeks later the proclamation was revoked. Provost Marshals had been appointed, the privilege of the writ of habeas corpus suspended in case of the rioters. It had the necessary effect and peace and tranquility were restored. In connection with the use of troops on this occasion a curious controversy arose between the General and the Secretary of War. As soon as Gibbon heard of the crisis he mobilized his forces ready to proceed to seattle at a moment's notice. He was rebuked by the Adjutant General of the army in these terms: "The Secretary of War thinks it would have been part of wisdom to keep secret any contemplated movement of 
troops, especially when connected with civil trouble". This took place February 9, 1886, and curious as it may sound, the very next day after the admonition General Gibbon was ordered to proceed to Seattle. Everything became quiet with the arrival of the regular. army. General Gibbon, however, suggested to Governor Squires, "that martial law is by your proclamation still in existence and in my opinion advantage should be taken of it to arrest every known leader of the late outrages." Gibbon then proceeded to ald the Governor in this work. Here Gibbon, it seems, went beyond the authority conferred upon him and he promptly received another telegram from the Adjutant General in these terms: "The remark, in a telegram from the Governor of Washington Territory to the Secretary of War 'that arrests of leaders are being made by General Gibbon' creates the impression that you have not clearly comprehended the purpose for which the troops were sent to seattle.... not as a posse comitatus.... but to preserve peace and give security to life and property .... If the condition of affairs at seattle or elsewhere..... was such that the functions of the local 
judiciary were virtually suspended by acts of violence and the ordinary process could not issue..... report. ... should have been made, when orders if deemed necessary would have been issued.' Gibbon's answer explained that he "was sent.... to aid civil authority and assist in the execution of the laws. The city being under martial law, the only civil authority... to aid was the governor."

This important controversy between the military commander and his chief brings out several salient facts; first, the amenability of the soldier to his superior as a check upon the exercise of arbitrary power, and second, the dilemna of the soldier. He must look to his superiors for orders, be subject to reprimand if he oversteps the bounds laid down by his chief, or be condemned for negligence if in the absence of instructions he fails to act.

During this same year occurred a very serious uprising in the city of Chicago, when a bomb was thrown by an anarchist into a crowd, killing many policomen and civilians and injuring many others. The Chicago police force arose to the occasion and gave an excelient 
account of itself, suppressing the riot without any assistance from any other source.

\section{VII.}

The next troublesome period in American History began about 1892 and since that time the regular army has been called on time and again to help maintain order in the United States. Most fortunately the state forces have been greatly strengthened since 1877 and the fraternizing with the mob, which became so con-

1. spicuous in the Pennsylvania troubles have become very few, General Schofield in his annual report of 1892 states, "that in all cases save two the National Guard had proved sufficient". This particular year was marked by such famous atruggles as the Homestead Riots in Pennsylvania, railroad strikes of switchmen in Buffalo and disturbances in Coel Creok, Tennessee caused by the use of convict labor in the mines. 
The first of the notable exceptions referred to by General schofield took place in Wyoming when parties of citizens took up arms to settle their local differences. The second incident occurred in the famous Coeur d' Alene district, Shoshone County, Idaho, which has been on many occasions since then the scene of mutinous riots and uprisings. The struggle began between the union and non-union men. Both were fully armed. The Miners Union was well organized and carried on a reign of terror. Winchester rifles and dynamite were freely used. On July 13 the Governor declared Shoshone County in a state of insurrection. July 15 the Fresident issued his proclamation and sent federal troops to the scene, State troaps were already there. Their commander removed the sherIff and appointed another in his place and made other changes in the local administration. The influence of the regular army was purely moral and not physical. General Burgess in reporting the situation sais that

1. "the mere appearance of the troops extinguished open lawlessnegs in the whole Coeur d' Alene mining region and no loss of life became necessary in the execution 
of duties devolving upon troops."

A crisis in the American industrial situation in 1894 brought the regular army into the field as the most powerful law-enforcing agency in the country. A business depression followed by a financial crisis prompted the Pullman Palace Car Company to reduce the wages of its employees, many of whom were members of the American Railway Union. The labor organizations? at tempts at arbitration failed and a strike was called. The railroad men positively refused to handle Pullman cars. The strike spread all over the country but the chief struggle took place in the city of chicago. The strike quite naturally interfered with the national government since the United States mails were usually carried on the fast trains to which Pullman cars were attached. In the meantime the strike had become a riot. The efficient Chloago police force which in 1886 quelled the anarchistic uprising at Haymarket Square was probably through sympathy for the strikers, unable to handle the situation. The president ordered 2000 regulars to Chicago. They arrived July 4 and even they were unable to quell the trouble at first. The mob ignored the injunction of the United 
States court, burned and destroyed railroad buildings and cars, and obstructed traffic on all of the twentythree railroads that passed through Chicago. Anarchy was threatened but instead of trying to quell the disturbance by the local police or geting any cooperation from the federal authorities we find the governor protesting against the use of regulars. The President, therefore, unable to send troops to Chicam go under the constitutional clause providing for the use of the army upon aplication of the state authorities in case of domestic violence, sent them of his own accord. This brought up a constitutional question which the courts decided in favor of the President. On July 8 the President issued a proclamation of warning and ample re-enforcements followed. The riot was checked. By July 20 peace had been restored and the federal troops were withdrawn. During this trouble Eugene V. Debs was arrestad upon an indictment for complicity in the obstruation of mails. A week later he was brought up for contempt of court and his case went to the Supreme Court on a writ of habeas corpus. The court upheld the 
President. Since interstate commerce and transportation of mails are foderal functions the United States government, the court held, is authorized to use the necessary means to prevent their obstruction.

Although during this troublesome period all eyes were focused upon Chicago, very serious diffi1. culties had also developed on the Pacific Coast. Here the country suffered because of the small size of the army. The Chicago strike had spread to Los Angeles and Colonel Shafter appeared with troops to make possible the transcontinental service of mail and commerce. He was acting under orders from the president "to employ military force to remove obstructions to mails and interruptions of interstate commerce on the Central Pacific Railroad and just such protection as to insure to the government the use of such railroad for postal, military or other governmental purposes". The state troop called out to maintain order had falled. Order was being established in Los Angeles when serious outbreaks occured in sacramento. In the latter, 3000 armed strikers held the situation in hand. General Rogers found that he did not have enough men to take care of 
the strike in both places so he asked for marines from Mare Island. His request brought a Battalion and these together with the soldiers established order. In the meantime the Department of platte was being stripped of its soldiers to reinforce the Coast. In secramento a train had been derailed, killing four soldiers and the engineer. Before the marines arrizod the soldiers of Battery L, 5th Artillery had been scattered in small detachments along the railroad. Here the exceptional scene of missiles being thrown at the federal troops was witnessed and what is even more exceptional, firing of the troops themselves. They were attacked first however and the right to defend themselves in such a case has never been questioned. The difficulties in California did not end with Sacramento. Oakland, an important railroad terminal was next to succomb to the strike fever. With the small detachments of the army scattered through the whole state of California, and with marines in Sacramento there was only one potential military force left. General Rogers obtained the use of sailors and more marines and then organized them as infantry with gun detachments and gatling guns. The military forces 
were victorious and with the exception of the one incident in Sacramento there was no bloodshed nor even serious difficulty after the troops arrived.

It is difficult to realize how mucb work the small force of regulars was called upon to perform

1. during this trying period. The coxeyite troubles were causing great concern in the northwest- in Montana and also in the Department of Columbia. In the latter Coxey's army.stole a tráin to take thein to Washington only to be intercepted by the regulars. The Pullman strikes caused many riots in these districts which were handled by the federal troops in the usual satisfactory manner.

A queer incident occurred in the Department of Colorado in this satue year. An attempt was made in Denver by the Governor to use the federal troops for political purposes. He had attempted to seat two new mombers in the police and fire departments to which severe opposition had been aroused. Denver had been the scene of riots before and the situation assumed a serious aspect. The city contained a federal mint and depository. The Governor asked for assistance from

1. Report Secretary of War 1895

2. Ibid 
General McCook. The General tact fully refused the Governor's request for assistance in taking the city Hall from his political opponents. The presence of the troops however had the moral effect of breaking up the riot.

The last conspicuous case of the nineteenth century involving the use of the regular army took place in the Coeur d' Alene region in 1899. The difficulties that arose in 1892 were far from settled and the chronic trouble recurred over the same question of union and non-union labor. Governor staunenberg, called to the scene of hostilities found the situation beyond his control and reported that fact to Washington. The Adjutant General ordered Brigadier General Merriam of the Department of Colorado "to repair at once to the Capitol of the state and after conference with the authorities, thence ..... to the seat of action calline to your aid suck troops as may be most convenient, regardless of department Iines." The General immediately got in touch with the Governor and, after making a personal reconnaisance, accompanied by his aide, he issued orders for the immediate mobilization of troops in Shoshone 
County. It was estimated that there were about one thousand armed miners who were acting in open deftence of the law and had already destroyed much mining property and caused some bloodshed. The Governor seemed in doubt as to whother he should declare martial or not. He and the General had both agreed that the best way to break up the rioting would be to scrutinize closely all travel and detain suspected passengers. This was clearly an act under martial law and the GeneraI hesitated before taking the measure. He telegraphed to Washington and received approval for the suggestes action. The rioters learning of the aproach of the regulars began to flee toward spokane. The Governor, realizing that he was losing the opportunity of ridding the county of the agitators unless he arrested them, declared martial law. General Merriam proceeded to assist the governor in the arrest of all suspicious persons. Arrests multiplied quickly. Fugitives escaped to Montana, but General Merriam very discreetly prevented his troops from crossing into a neighboring atate to size the lawbreakers but left the matter to be settled between the two governors. 
Prisoners came in so fast that there were no accommodations for them. They were brought in cold and hungry and there was no food nor blankets. The troops, of course, were undergoing severe hardships at the same time. General Merriam protested against the herding of these prisoners into such uncomfortable and unsanitary quarters and urged the governor to make all haste in the examination of those arrested. The Governor responded and came down in person to carry on the work.

The Governor had in the meantime, served a notice on all the mine owners of the district, by which, during the continuance of martial law, they were forbidden to employ miners unless they were able to present permits from state authorities. An elaborate system for procuring these permits was provided. The proclamation was submitted to the General for approval and he suggested that a paragraph be inserted providing that an applicant must first deny participation in the riot of April 29, 1899, and second, to deny or renounce membership in any society which participated in or incited the riot. This paragraph was embodied in the proclamation and the General 
authorized his name to be printed on the bottom of the poster, under the words "examined and approved". This was the only connection that the military authorities had with the proclamation- No attempt was made to participate in the issue or enforcing of the permits. The General had merely approved the Governor's policy. Nevertheless, it did savor of military approval of a question purely of policy.

The labor unions quite naturally took exception to military sanction of an order which seemed to legislate against a union. They protested to Washington that miners in the Coeur a' Alene district are denied the right to employ men unless they make affidavits that they are non-union men and that the army is enforcing the order. To be sure, actual force was not being used but the moral force of the General's approval posted on the Governor's proclamation cannot be denied. The General denied that affidavits were required, claimed that this restriction applied anly to the unions that participated in the riots and was not an anti-union measure, and reiterated that troops were taking no part in this work. The telegram 
of May $3 I$ from the secretary of War to the ceneral has somewhat the tone of a reprimand..... Use the United states troops to aid the state authorities simply to suppress rioting and to maintain peace and order...... The army must have nothing whatever to do with enforcing rules for the government of miners or miner's unions. That is a matter for the local authorities to deal with."

The reign of terror of wanton destruction of lives and property was considerably calmed by the arrival of troops, and the emergency soon passed. The troops remained in the district until october 13.

VIII.

During the past twenty years the army has been called upon more frequently than ever before to maintain law and order where civil authorities have failed. To be sure nothing of the magnitude of the 
strikes of 1877 and 1894 have occurred but the calls have even more frequently come. The most conspicuous case, of course, was the San Francisco earthquake in 1905. General Funston of his own sccord called out the troops and had them report to the Chief of Police, Here we have the case of a military cowrander who, faced by a crisis, took matters in hand and was properI. Iy vindicated. "But for this action," says the secretary of War, "the city would soon have been in the hands of thugs and looters". The army maintained order and administered relief to the greatest satisfaction. The work stands out as one of the most notable accomplishments of the army of the United States.

Other emergencies have arisen during the past twenty years, but none involving new principles or unprecedented situations. The state militia and state constabularies have grown in strength and their mere appearance is begining to have somewhat the same moral effect as the presence of federal troops. The state constabulary of Pennsylvania is probably the best known in this respect.

Since the close of the European War the regu- 
Iar army has been kept constantly on the alert, ready to maintain peace in every troublesome region in the country. The reasons for the restlessness and exhibitions of lawlessness that have manifested themselves from time to time since November 1918 are many. We are not concerned with the causes. We must fact the facts and be prepared to prevent at any cost the wanton destruction of property and the frequent loss of lives that accompany these outbursts of lawlessness. No better conception of the extent to which the regular army has been called upon to maintain order can be obtained than a consideration of the actual calls the federal troops answered. Let us consider the year 1919-20 as a typical example. The following is a brief summary covering the use of federal troops in the establishment of law and order during that year 1. and speaks for itself:

$$
\begin{array}{ll}
\text { July } 1919- & \text { Arizona- I.W.W. uprising. } \\
& \text { Washington, D.C.- race riots } \\
\text { September - } & \text { Omaha, Nebraska- race riots- } \\
& \text { mob was on the point of } \\
& \text { hanging the city mayor. Gen- } \\
& \text { eral Wood was called in and } \\
& \text { the city had to be put under } \\
& \text { "qualified" martial law. }
\end{array}
$$


Knoxville, Tennessee; West VirginiaCoal strikes.

October-

Gary, Indiana, - strike among steel workers- General Wood called in again. Appearance of federal troops again restored order.

Elaine, Arkansas- race riots.

November- Strikes in the following places or districts- Wyoming; Utah; Brownsville, Pennsylvania; Gallup, New Mexico; Bayne, Washingt on; Bogalus, Louisiana; Pittsburg, Kansas; and McAllister, Oklahoma.

January 1920 Dumas, Mrkansas- negro uprising. February - Lexington, Kentucky- negro lynching. Montessamo, Washington- trial of persons charged with murder of members of American Legion.

April- Butte, Montana- strike.

This list is not complete. Nor does it mention the cases where the National Guard or municipal police met the emergency. It shows that the germs of internal troubles are sown in agricultural as well as in industrial centers, in the east as well as in the west, and noth as well as south. A nation must be prepared to defend itself against its lawless elements at all times. 
IX.

In considering the future size of the regular army this phase of preparedness must not be overlooked. Indications are that the call for troops will occur even more frequently in the future. We seem to be on the brink of a great laber uprising of which the coal strike, the West Virginit and Colorado troubles, and the averted railroad strike are but the symptoms. Labor struggles always mean strikes and lockouts accompenied by a certain degree of disorder which may suddenly take the form of a riot. The memory of the railroad strikes of 1877 is still fresh in the minds of many Americans.

The army will continue to be in the future as it has in the past, the main buiwark against lawlessness and terror; and in the future as in the past military cowmanders will be called upon to handle emerEencies which will require tact, force and humen understanding. The situation of the army officer in case of internal troubles is at best a precarious one, -placed as he is between a military court-martial on the one side, and a civil suit on the other. From the 
cases we have considered his delicate situation has been emphasised again and again. At the bottom, however, we find one cardinal principle, which is well known to all military men, and is as applicable to fighting foreign enemies as well as to guarding bridgen. A soldier muat be positige in his attitude. First he must study the problem before him, then he must act. He may decide that the mere presence of troops will quell the uprising, he way feel that there is no need for intervention at all, or he may conclude that force to the utmost is necessary. He must, however, decide upon some plan. Once having determined upon his plan of action he must see it through. Nothing so injures his prestige and consequently his ability to handle the situation as ailatory tactics, indefinite plans, and constant changes of front.

A study of the operation of martial law in this country must lead to another conclusion, and that is the moral effect of the mere appearance of the regular army. Time and time again that alone sufficed to break up a riot and restore law and order. There are many reasons for this. First and foremost 
there is the respect for the regular army so-ldier, his training and his ability to handle his weapons. Every schoal boy knows that "a regular can shoot". Another reason is the. fact that the regular army. is recruited from the country as a whole. A regiment of regulars called to perform riot duty in Chicago may have a dozen soldiers in its ranks to whom the city is anything more than a geographical acquaintance. On the other hand the local police force and the national guard may be called upon to face not only neighbors and friends but even relatives. The result is obvious. The average American is a law-abiding person, and that is why the average disturbance can be handled by recourse to the local police system. When, however, an acute situation develops which requires extreme measures, even to the extent of firing the average national guard company is put in a very delicate position. The final resort must be the regular army.

Here too, is another point worth considering. The regular army is the final resort, to be sure, and should therefore only be called upon.when all other means have failed. Furthermore, the responsibility 
belongs to the individual state, and there it should properly be lodged. Let each state develop its own police system with a full knowledge that behind it there is a powerful support of regular army soldiers who will stand bohind it and back it to the limit, but first it must learn to depend on itself. When everything else has failed, and there are times of such emergencies then, and then only, should the state appeal for federal aid.

The regular army has not developed a manual for the handing of internal disturbances, and there is one of its chief virtues. Every case is complete in 1tself. There is nothing stereotyped as to what a military commander should or should not do. He merely knows that his initiative, tact, and ability as a military leader have been put to the test. The rest is with him. He may make himself hated by the very persons ho is called upon to protect, or he may be a subject of admiration and respect by all factions. He may be hailed before a court, reprimanded and finied as was General Jackson; rebuked by his own superior as happen- 
od to General Merriam; or hailed by his country as a public hero as General Funston in the San Francisco earthquake. The matter is entirely in his own hands. On the whole it must be admitted that the American regular has met the test and has not been found wanting. 


\section{BIBLIOĠRAPHY}

Reports of the Secretary of War-U.S. Government publications- 1841-1920 inclusive- Washington, D.C.

Dicey- Law of the Constitution, 6 th EditionLondon- MacMilian \& Co.- 1902.

Berkheimer- Military Government and Martial Law Kansas City - FrankIin Co. - 7914.

Manual Court Martial- U.S. Government publication War Department, Washington, D.C. 1920.

Lowell-Government and Parties in Continental Europe - Boston - Houghton and Miffin Co. - 1896.

Winthrop - Military Law and Precedents, 6th Edition - Washington, D.C. - Government publication- 1920. 2 Volumes.

Stephen- History of the Criminal Law of England London - MacMialan - 1883. 3 Volumes.

Bancroft - History of the United States - BostonLittle, Brown and Co. - 1874. 10 Volumes.

Martyn- Life of Artemas Ward - New York -

A. Ward Co: - 1921 .

Irving- Life of George Washington- Irving's WorksNew York - Collier- 1897. Volumes 12-15.

Randall- Life of Thomas Jefferson- New York Derby - 1858. 3 Volumes.

Fiolt \& Co.- 1919.

Fiske,-American Diplomacy - New York - Henry \& Co.- 1893.

Parton-General Jackson - New York - D. Appleton

Carpenter - Military Government, Southern Territory - American Historical Association- 1900. 
- Bibliography, Cont'd.

War of the Rebellion Official Records of the Union and Confederate Armies - Government Publication 1902 Series I, Vols. $3,4,6,7,8,9,10,11,13,14,15,16,17,22,23$, $27,35,37,319,49,50,51,52$. Series II, Vols: $1,2,3,4,5$.

Series III, Vols. 1,3,4,5.

Series IV, Vols. 1,2.

Rhodes- History of the United States - New YorkMacMillan- 1919. 7 Volumes. 